\title{
Pengaruh Motivasi Belajar dan Pemanfaatan Perpustakaan Terhadap Prestasi Belajar (Studi Pada Mahasiswa Pendidikan Ekonomi Universitas Pamulang Tahun 2018/2019)
}

\author{
FITRA JAYA
}

Dosen Program Studi Pendidikan Ekonomi Universitas Pamulang

*) email: $\underline{\text { dosen02167@unpam.ac.id }}$

\begin{abstract}
ABSTRAK
Motivasi belajar dan pemanfaatan perpustakaan merupakan bagian dari komponen sistem pembelajaran. Tanpa motivasi dan didukung dengan pemanfaatan perpustakaan yang optimum oleh mahasiswa akan sulit dicapai prestasi belajar yang baik. Penelitian ini bertujuan untuk mengetahui pengaruh motivasi belajar dan pemanfaatan perpustakaan terhadap prestasi belajar mahasiswa. Penellitian ini merupakan penelitian kuantitatif deskriptif. Penelitian ini merupakan penelitian polulasi dengan melibatkan seluruh objek penelitian. Metode pengumpulan data yang digunakan untuk variabel bebas meliputi angket atau kuisioner, sedangkan variabel terikat digunakan data prestasi belajar mahasiswa dan dokumentasi sebagai data pendukung. Berdasarkan hasil uji analisis regresi linear berganda dengan menggunakan softwere IBM SPSS 22 didapatkan nilai signifikansi sebesar 0,000 < $\alpha(0,05)$, dan nilai thitung 19,278 dengan nilai ttabel 3,15. Hal tersebut menunjukkan bahwa terdapat pengaruh yang positif dan signifikan antara motivasi belajar dan pemanfaatan perpustakaan terhadap prestasi belajar.
\end{abstract}

\section{Kata Kunci: Motivasi, Prestasi, Perpustakaan}

\section{PENDAHULUAN}

Pembelajaran merupakan sebuah sistem yang didalamnya terkandung beberapa unsur penting sehingga dapat terciptanya hasil terbaik dari proses pembelajaran. Hasil dari proses pembelajaran yang baik tersebut

$$
\begin{aligned}
& \text { diharapkan dapat memberikan } \\
& \text { kontribusi yang nyata bagi } \\
& \text { pembangunan bangsanya. Seperti } \\
& \text { diketahui bahwa hakekat dari } \\
& \text { pembangunan nasional adalah } \\
& \text { pembagunan dari aspek sumber daya } \\
& \text { manusia seutuhnya dan seluruhnya, }
\end{aligned}
$$


karena maju mundurnya suatu bangsa ditentukan oleh seberapa baik kualiatas pendidikan yang ada didalamnya. Upaya untuk meningkatkan kualitas pendidikan selalu dilakukan untuk menjamin terselenggaranya pendidikan yang mampu menyesuaikan dengan tuntutan seiring dengan laju perkembangan jaman dan globalisasi yang begitu pesat. Pembaharuanpembaruan dalam bidang pendidikan baik dari segi kurikulum, bahan ajar, media, metode, sampai dengan peningkatan kualiatas tenaga pengajar tidak lain bertujuan untuk memberikan pelayanan pendidikan yang terbaik bagi setiap warga negara, sehingga dapat mempersiapkan generasi mendatang untuk dapat memiliki pengatahuan dan kemampuan menghadapi tantangan globalisasi.

Berdasarkan jenjang pendidikan, penyelenggaraan pendidikan di Indonesia terbagi menjadi beberapa tingkatan diantaranya yaitu jenjang pendidikan dasar, jenjang pendidikan menengah, hingga jenjang pendidikan tinggi. Keseluruhan dari jenjang pendidikan tersebut memiliki karakteristik dan tujuan pencapaian belajar yang berbeda-beda, akan tetapi keseluruhannya berfokus pada pencapaian prestasi belajar yang optimal bagi peserta didiknya, baik untuk siswa maupun mahasiswa. Penyelenggaraan pendidikan pada level pendidikan tinggi setidaknya melibatkan beberapa stakeholder didalamnya seperti mahasiswa, dosen, orang tua maupun lembaga pendidikan tinggi yang keseluruhannya saling memberi pengaruh untuk dapat menciptakan prestasi yang diharapkan.

Berdasarkan hasil observasi awal pada mata kuliah ekonomi pembangunan reguler A program studi pendidikan ekonomi universitas pamulang, ditemukan bahwa belum optimalnya prestasi belajar yang dicapai. Hal tersebut berdasarkan hasil kuis mata kuliah ekonomi pembanguan dari sebanyak 61 mahasiswa, hanya 25 yang berada pada rentang nilai A dan B, sebanyak 36 mahasiswa lainnya bervariasi pada rentang nilai C, D dan E. Secara otomatis hal ini menuntut untuk dilakukannya evaluasi secara menyeluruh dalam suatu sistem pembelajaran. Mata kuliah ekonomi pembanguan dipandang sebagai salah satu mata kuliah prasyarat, dimana mata kuliah tersebut memberikan 
gambaran/ikhtisar kepada para mahasiswa terkait dengan pembangunan perekonomian dalam sebuah negara. Mengingat pentingnya mata kuliah tersebut diharapkan setidaknya terdapat minimal lebih dari $75 \%$ mahasiswa berada pada rentang nilai A dan B. Observasi dilanjutkan dengan melakukan wawancara kepada beberapa mahasiswa terkait dengan diagnosa kesulitan dalam belajar. Sebagian mahasiswa menuturkan bahwa meraka belum sepenuhnya memanfaatkan fasilitas perpustakaan sebagai sarana memperdalam kajian pustaka pada materi yang disajikan oleh dosen pada setiap kegiatan pembelajarannya.

Fasilitas perpustakaan memilki peranan yang penting sebagai sarana pendukung kegiatan pembelajaran. Perpustakaan menjadi sebuah sumber informasi mengenai ilmu pengetahuan dan teknologi yang mampu mengakomodasi seluruh kebutuhan belajar mahasiswa sehingga dapat memperluas wawasan pengetahuan. Mahasiswa tidak seluruhnya memiliki buku pegangan yang menunjang kegiatan belajar mengajar, sehingga menjadi sangat penting kiranya pemanfaatan perpustakan menjadi salah satu faktor eksternal dalam kegiatan belajar mengajar.

Darmono (2004: 2) menyatakan bahwa perpustakaan sebagai salah satu unit kerja yang berupa tempat untuk mengumpulkan, menyimpan, mengelola dan mengatur koleksi bahan pustaka secara sistematis untuk digunakan oleh pemakai sebagai sumber informasi sekaligus sebagai sarana belajar yang menyenangkan. Ibrahim (2005: 3) Mendefinisikan perpustakaan sebagai suatu unit kerja dari lembaga atau badan tertentu yang mengolah bahan-bahan pustaka baik berupa buku maupun bukan berupa buku yang diatur menurut aturan tertentu untuk dapat digunakan sebagai sumber informasi. Perpustakaan dapat dipahami sebagai sebuah sarana penunjang yang dapat memfasilitasi mahasiswa agar dapat berinteraksi secara langsung dengan berbagai sumber-sumber belajar yang tersedia.

Pencapaian hasil belajar yang optimal merupakan sebuah tujuan ahir dalam proses pembelajaran, akan tetapi dalam prakteknya banyak ditemui beberapa faktor-faktor yang kompleks dan hal tersebut memberi dampak terhadap pencapaian hasil belajar. Faktor tersebut dikelompokkan menjadi 
dua, yaitu kelompok faktor internal dan kelompok faktor eksternal. Faktor internal secara sederhana diartikan sebagai faktor yang berasal dari dalam diri dan bersifat fisik maupun psikis, seperti sikap, intelegensi, minat bakat, kemandirian, kepribadian dan sebagaianya. Sedangkan faktor eksternal dapat diipahami sebagai sebuah faktor yang mempengaruhi berasal dari luar seperti lingkungan sosial, fasilitas kampus, kondisi cuaca dan lain sebagainya. Ibrahim (2005: 6) menyatakan terdapat beberapa fungsi perpustakaan seperti fungsi edukatif, fungsi informatif, fungsi tanggung jawab administratif, fungsi riset, fungsi rekreatif.

$\begin{array}{lrr}\text { Sebagai } & \text { fungsi } & \text { edukatif } \\ \text { perpustakaan berperan } & \text { menyajikan } \\ \text { buku-buku yang dapat } & \text { membiasakan } \\ \text { mahasiswa agar dapat belajar secara }\end{array}$
mandiri. Perpustakaan menyediakan berbagai macam informasi baik cetak maupun non-cetak serta koleksi lainya yang dapat membantu mahasiswaa dalam memberikan informasi atau keterangan-keterangan yang dibutuhkan dalam dunia perkuliahan. Kelengkapan bahan pustaka didalam perusahaan akan membantu mahasiswa dan dosen dalam pelaksanaan riset dan mengumpulkan data atau keterangan yang diperlukan dalam menunjang kegiatan pembelajaran. Kelengkapan bahan pustaka yang memadai dan sesuai dengan kebutuhan mahasiswa akan memacu untuk menggunakan sebagian waktu luangnya untuk mengunjungi perpustakaan, sehingga diharapkan perpustakan dapat menjadi sarana refresing dan tempat yang nyaman bagi mahasiswa. Dapat dupahami bahwa pemanfaatan perpustakaan adalah suatu aktifitas yang seharusnya dilakukan oleh mahasiswa sebagai sarana menambah serta memperluas khasanah ilmu pengetahuan dalam lingkungan masyarakat ilmiah, baik sebagai sarana riset maupun pengembanganpengembangan ilmu pengetahuan lainnya.

Disisi lain dari faktor intern motivasi belajar menjadi bagian penting dalam diri seorang mahasiswa untuk dapat membiasakan diri dalam mengkaji bahan-bahan pelajaran yang menjadi tuntutan setiap mata kuliah. Sudirman (2004: 75) menyatakan bahwa motivasi adalah keseluruhan daya penggerak yang berasal dari dalam diri subjek belajar sehingga dapat menimbulkan 
kegiatan belajar dan memberikan arahan pada kegiatan belajar tersebut. Membangun motivasi pada subjek didik merupakan hal yang paling penting yang dilakukan oleh pengajar/dosen. Motivasi dalam belajar bukan sekedar menggerakkan tingkah laku tetapi juga dapat membimbing dan memperkuat kemauan dan kemampuan mahasiswa dalam belajar agar dapat mengembangkan dirinya secara maksimal selama masa perkuliahan. Motivasi sangat erat kaitannya dengan tujuan, mahasiswa yang memiliki tujuan yang kuat untuk apa mereka belajar, maka juga akan memiliki motivasi yang tinggi untuk belajar. Mahasiswa yang memilki motivasi yang tinggi dalam belajar dapat terlihat dari ketekunan, minat dan kegairahan yang serius dalam belajar. Secara sederhana dapat dipahami bahwa motivasi belajar sebagai keseluruhan daya penggerak dari dalam diri mahasiswa yang dapat menimbulkan minat yang serius dalam kegiatan belajar sehingga tujuan yang mereka kehendaki dapat tercapai.

Motivasi dapat dibagi dua yaitu motivasi intrinsik dan motivasi ekstrinsik (W.S Winkel, 2004:173). Motivasi intrinsik merupakan suatu keadaan dimulainya aktivitas kegiatan belajar yang selanjutnya diteruskan atas dasar penghayatan pada suatu kebutuhan dan dorongan yang kuat atas aktivitas yang dilakukan tersebut. Sedangkan Djamarah (2002:115) berpendapat bahwa motivasi intrinsik merupakan motif yang aktif dan fungsinya tidak memerlukan pengaruh dari luar, dikarenakan dalam diri seseorang telah ada suatu dorongan untuk melakukan sebuah aktifitas. Motivasi intrinsik dapat disama artikan dengan motivasi murni karena motivasi ini timbul dari kesadaran diri mahasiswa. Hal tersebetut dapat dilihat dari tingkat kesadaran pada diri mahasiswa dengan tujuan belajar yang mendorongnya untuk melakukan kegiatan belajar, bukan karena dipengaruhi oleh faktor luar namun karena faktor energi dan pengaruh yang datang diri mahasiswa. Keaktifan mahasiswa dalam kegiatan belajar mengajar berkaitan erat dengan minatnya terhadap mata kuliah tertentu yang beraneka ragam, kegiatan tersebut berupa membaca kegairahan buku pelajaran, mendengarkan penjelasan materi dari guru, menulis atau mencatat jika ada materi yang penting. Selain itu 
siswa yang mudah menghapal pelajaran yang menarik minatnya. Minat merupakan alat motivasi yang utama yang dapat membangkitkan dalam belajar dalam rentang waktu tertentu. Motivasi ekstrinsik adalah motif-motif yang aktif dan berfungsi karena adanya perangsangan dari luar (Djamarah, 2002 :117). Oemar Hamalik (2003:175) berpendapat bahwa motivasi berfungsi:

1) Pendorong munculnya suatu tindakan atau perbuatan. jika tidak memiliki motivasi maka tidak timbul suatu tindakan atau perbutan seperti belajar.

2) Sebagai pengarah, motivasi berperan mengarahkan tindakan atau perbuatan pada suatu pencapaian tujuan yang dikehendaki.

3) Sebagai penggerak. dapat dipahami bahwa besar kecilnya motivasi yang dimiliki oleh seseorang menjadi penentu cepat atau lambatnya suatu pekerjaan

Sehingga dapat di pahami bahwa motivasi baik itu yang berasal dari dalam diri maupun yang berasal dari luar sangat diperlukan mahasiswa untuk menjadi tekun dan bersemangat dalam belajar. Berdasarkan uraian diatas tujuan yang ingin dicapai dalam penelitian ini adalah untuk mengetahui pengaruh motivasi belajar dan pemanfaatan perpustakaan terhadap prestasi belajar.

\section{METODE PENELITIAN}

Penelitian adalah sebagai usaha untuk menemukan, mengembangkan dan menguji kebenaran suatu pengetahuan, usaha mana dilaksanakan dengan menggunakan metode ilmiah (Sutrisno, 2000: 24). Pendekatan dalam penelitian ini menggunakan pendekatan kuantitatif, dengan memberikan penekanan pada pengujian varibel dalam penelitan melalui angka dilanjutkan dengan analisis data melalui prosedur statistik. Berdasarkan judul penelitian, maka penelitian ini dilaksanakan pada Program Studi Pendidikan Ekonomi Universitas Pamulang.

Penelitian ini merupakan penelitan populasi dengan melibatkan seluruh subjek penelitan yang berasal dari kelas Reguler A semester 6 program studi pendidikan ekonomi universitas pamulang tahun pelajaran 2018/2019. (Sugiyono, 2010: 80) menyatakan bahwa "Populasi adalah wilayah generalisasi yang terdiri atas: 
objek/subjek yang mempunyai kualitas dan karakteristik tertentu yang ditetapkan oleh peneliti untuk dipelajari dan kemudaian diatarik kesimpulanya".

Sumber data yang digunakan dalam penelitian ini menggunakan sumber data primer dan sekunder. Sumber data primer diperoleh melalui angket yang disebarkan kepada responden, sedangkan sumber data sekunder diperoleh dari dokumentasi untuk mengetahui secara umum gambaran data siswa dan sekolah. Teknik analisis data yang digunakan dalam penelitian ini adalah analisis deskriptif dan inferensial. Analisis deskriptif bertujuan untuk memberikan gambaran skor minimu, maksimum, variance, mean, range, standar deviasi, sum. Analisis inferensial terdiri dari uji pra-syarat analisis dan uji hipotesis.

Uji pra-syarat analisis terdiri dari uji normalitas resiudal, uji multikoliniearitas, dan uji heteroskedestisitas. Selanjutnya apabila dinyatakan telah memenuhi syarat maka dilakukan uji-t, uji-F dan koefesien determinasi.

\section{HASIL DAN PEMBAHASAN}

Deskripsi data variabel penelitian diperoleh dari hasil penyebaran angket yang diberikan kepada 61 mahasiswa sebagai subyek penelitian dan transkip nilai rata-rata mahasiswa pada nilai UTS semester genap tahun pelajaran 2019. Angket yang digunakan dalam pengambilan data terlebih dahulu dilakukan uji coba untuk mengetahui validitas dan realibilitasnya. Berdasarkan hasil uji validitas dan reaibilitas instrumen penelitian berupa angket dari 25 butir soal yang mewakili indikator motivasi belajar yang diajukan untuk uji coba isntrumen, diperoleh hasil bahwa 20 soal dinyatakan valid dan reliabel. Pada indikator variabel pemanfaatan perpustakaan sekolah dari 25 soal yang diujicobakan, 18 soal dinyatakan valid dan reliabel. Selanjutnya instrumen yang telah dinyatakan valid dan reliabel dipergunakan sebagai instrumen pengambilan data penelitian dengan deskripsi sebagai berikut:

\section{Uji Pra-syarat Analisis}

Tahap awal sebelum dilaksanakan analisis regresi adalah terpenuhinya uji pra-syarat analisis pada data yang telah dikumpulkan. Tujuan uji pra-syarat 
analisis ini adalah untuk memberikan kepastian/ketepatan bahwa yang dikumpulkan kemudian akan memiiliki persamaan regresi yang dihasilkan memiliki tidak bias, memiliki ketepatan dan konsisten. adapun uji pra-syarat analisis yang diterapkan meliputi: uji normalitas residual, uji multikolinearitas dan uji heteroskedastisitas, dengan pemaparan hasil sebagai berikut:

\section{a. Uji Normalitas data}

Pada tahap awal data yang dikumpulkan selanjutnya dilakukan uji normallitas kolmogrov smirnov.

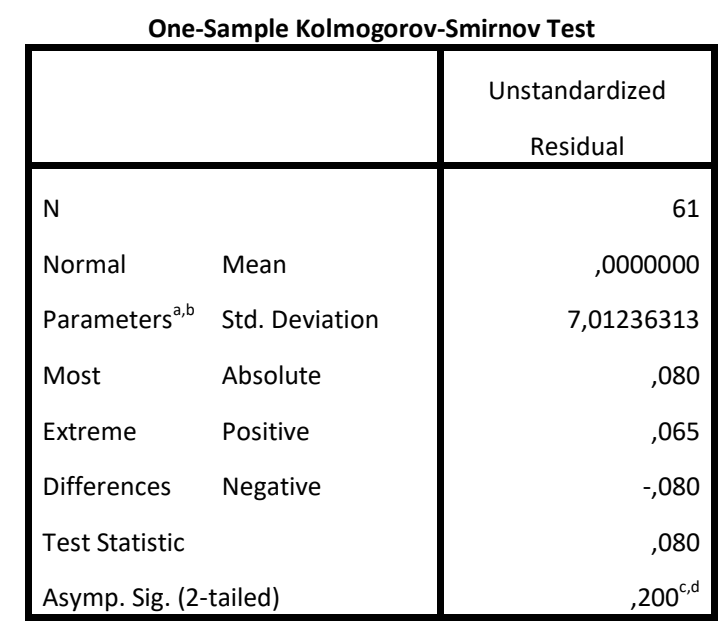

Diperoleh hasil Asymp. Sig. (2-tailed) = $0,200>0,05$ yang dinyatakan bahwa data tersebar secara normal.

\section{b. Uji Mutlikolinearitas}

Gejala multikolonearitas dapat diketahui dengan merujuk pada nilai (VIF dan tolerance. Apabila nilai VIF kurang dari 10 dan tolerance lebih dari
0,1, maka dapat dinyatakan bahwa tidak terdapat multikolinearitas (Ghozali: 2001). Berdasarkan hasil perhitungan statistis diperoleh data bahwa VIF = 1,637 dan Tolerance 0,611. Berdasarkan teori diatas dinyatakan bahwa tidak terdapat gejala multikolinearitas

\section{c. Uji Heteroskedastisitas}

Berdasarkan hasil analisis statistik yang telah dilakukan, titik-titik pada sumbu Y menyebar diatas dan dibawah angka 0. Merujuk pada fenomena tersebut dapat diambil kesimpulan bahwa tidak terjadi masalah heteroskedastisitas data pada model regresi.

Berdasarkan hasil uji pra-syarat analisis regresi diatas dapat disimpulkan bahwa data yang terkumpul memiliki ketepatan dan estimasi, tidak bias dan konsisten, sehingga memenuhi syarat untuk dilakukan analisis regresi linear berganda.

\section{Pengujian Hasil Analisis Data}

\section{a. Uji-t}

Uji-t digunakan untuk mengetahui besarnya pengaruh secara parsial atau terpisah antara variabel bebas dan 
variabel terikat dengan hasil sebagai berikut:

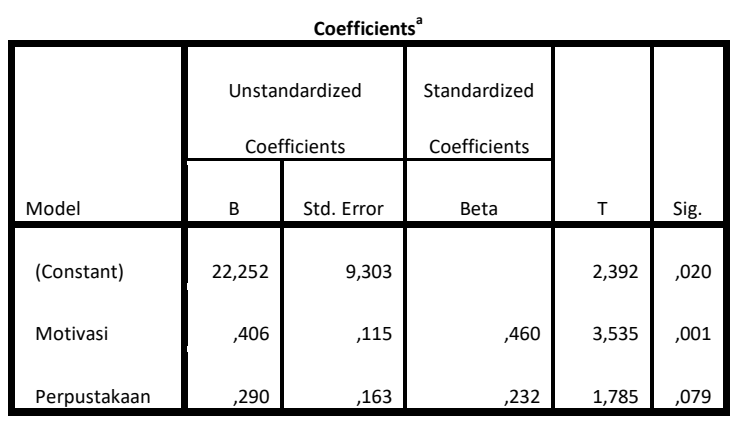

Dependent Variable: Prestasi

1) Pengaruh antara variabel motivasi belajar (X1) terhadap prestasi belajar (Y)

Berdasarkan dari perhitungan data analisis statistik untuk variabel motivasi belajar (X1) diperoleh nilai signifikansi $0,001<0,05$, dan diperoleh thitung 3,535> tabel 2,002 pada taraf signifikansi $5 \%$. Berdasarkan hasil perhitungan statisttik diatas dapat disimpulkan bahwa motivasi belajar memiliki pengaruh yang positif dan signifikan terhadap prestasi belajar.

2) Pengaruh antara variabel pemanfaatan perpustakaan (X2) terhadap prestasi belajar

Berdasarkan dari perhitungan data analisis statitik untuk variabel pemanfaatan perpustakaan diperoleh nilai signifikansi sebesar $0,079>0,05$, dan diperoleh nilai thitung $1,784<$ tabel 2,002 .

Berdasarkan hasil perhitungan data statistik diatas dapat disimpulkan bahwa tidak terdapat pengaruh yang signifikan antara pemanfaatan perpustakaan dengan prestasi belajar.

\section{b. Uji-F}

Uji-F digunakan untuk mengetahui besarnya pengaruh secara serempak atau bersama-sama antara variabel bebas Motivasi belajar (X1) dan Pemanfaatan Perpustakaan (X2)

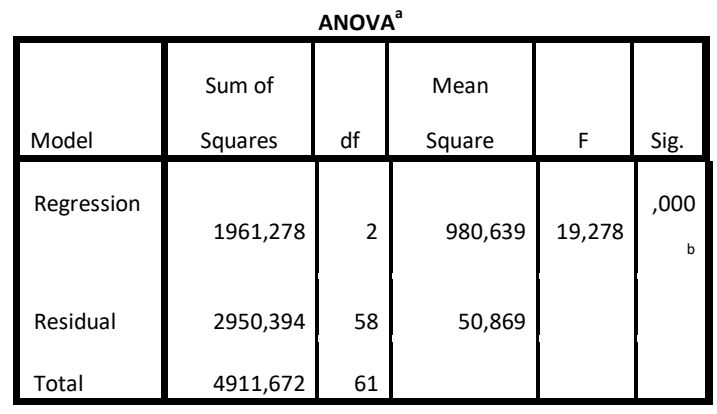

a. Dependent Variable: Prestasi

b. Predictors: (Constant), Perpustakaan, Motivasi terhadap Prestasi Belajar (Y), dengan pemaparan data sebagai berikut:

Berdasarkan hasi dari pengujian diperoleh nilai signifikansi sebesar $0,000<0,05$, dan nilai Fhitung 19,278> Ftabel 3,15 pada taraf signifikansi 5\%. Maka dapat disimpulkan bahwa terdapat interaksi pengaruh yang positif dan signifikan antara Motivasi Belajar (X1) dan Pemanfaatan Perpestakaan (X2) terhadap Prestasi belajar (Y). 


\section{c. Analisis Koefisien Determinasi}

Untuk mengetahui presentase pengaruh variabel independen yaitu motivasi belajar dan pemanfaatan perpustakaan terhadap variabel dependen yaitu prestasi belajar dilakukan analisis koefisien determinasi. Hasil analisis koefesien determinasi disajikan dalam tabel berikut:

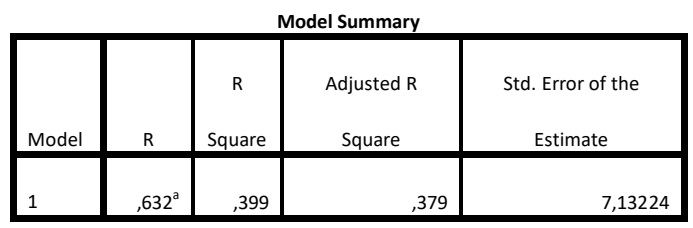

a. Predictors: (Constant), Perpustakaan, Motivasi

Berdasarkan tabel diatas, dapat terlihat bahwa koefisien determinasi dalam penelitian ini adalah nilai $R$ Square sebesar 0,399. Besarnya nilai koefisien 0,399 sama dengan 39,90\%. Nilai tersebut berarti bahwa sebesar $39,90 \%$ prestasi belajar mata kuliah ekonomi pembangunan pada mahasiswa progam studi pendidikan ekonomi Universitas Pamulang dapat dijelaskan melalui motivasi belajar dan pemanfaatan perpustakaan. Sebesar $60,10 \%$ sisanya dipengaruhi oleh variabel lain yang tidak disertakan dalam penelitian ini.

\section{SIMPULAN DAN SARAN}

\section{a. Simpulan}

Berdasarkan data yang terkumpul dari pengujian dan pembahasan hasil penelitan yang dilakukan peneliti pada mata kuliah ekonomi pembangunan mahasiswa program studi pendidikan ekonomi universitas pamulang tahun pelajaran 2018/2019 dengan mengggunakan taraf signifikansi 5\% dapat disimpulkan sebagai berikut:

1) Ada interaksi pengaruh yang signifikan antara motivasi belajar dan pemanfaatan perpustakaan terhadap prestasi belajar

2) Ada interaksi pengaruh yang signifikan antara motivasi belajar terhadap prestasi belajar

3) Tidak ada pengaruh yang signifikan antara pemanfaatan perpustakaan terhadap prestasi belajar

4) Motivasi belajar dan pemanfaatan perpustakaan menyumbangkan pengaruh sebesar

\section{b.Saran}

Berdasarkan kesimpulan hasil penelitian yang telah diuraikan diatas, maka dapat diajukan saran-saran sebagai berikut: 
1) Bagi Universitas

Pihak pengelola perpustakaan hendaknya menambah koleksi buku-buku dan meningkatkan kualiatas pelayanan. Dengan demikian diharapkan perpustakaan menjadi suatu tempat yang nyaman dan produktif bagi mahasiswa untuk meningkatkan referensi kepustakaan.

2) Bagi Dosen

a. Dosen perlu memberikan dorongan pada mahasiswa untuk dapat memanfaatkan perpustakaan secara optimal, sehingga diharapkan dapat memberikan dampak yang positif terhadap hasil belajar.

b. Dosen hendaknya memberikan motivasi belajar terhadap mahasiswanya, baik pada proses pembelajaran berlangsung maupun diluar kegiatan belajar mengajar

3) Bagi Mahasiswa
a. Mahasiswa
hendaknya mempunyai inisiatif sendiri untuk memanfaatkan perpustakan untuk mendalami serta menambah wawasan.

b. Mahasiswa harus meningkatkan motivasi belajarnya untuk memperkaya khasanah dan mengembangkan ilmu pengetahuan.

\section{DAFTAR PUSTAKA}

Darmono. 2004. Manajemen dan Tata Kerja Perpustakaan Sekolah. Jakarta: Grasindo

Ibrahim Bafadal. 2005. Pengelolaan Perpustakaan Sekolah. Jakarta: Balai Pustaka

Oemar Hamalik. 2003. Psikologi Belajar dan Mengajar. Bandung: Sinar Baru

Sardiman.A.M. 2004. Interaksi dan Motivasi Belajar Mengajar. Jakarta: Rajawali

Sutrisno Hadi. 2001. Analisis Regresi. Yogyakarta: Andi Offset

Syaiful Bahri Djamarah. 2002. Psikologi Pengajaran. Jakarta: Rineka Cipta

W.S.Winkel. 2004. Psikologi Pengajaran. Jakarta: Gramedia 